\title{
Effect of Aqueous Fruit Extract of Cucumis Sativus on Some Biochemical Parameters in Streptozotocin Induced-Diabetic Rats
}

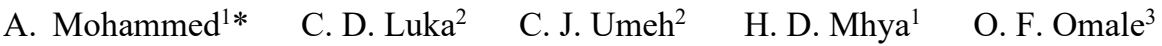 \\ 1.Department of Biochemistry, Faculty of Basic Medical Sciences, College of Medical Sciences, Abubakar \\ Tafawa Balewa University (ATBU), Bauchi \\ 2.Department of Biochemistry, Faculty of Basic Medical Sciences, University of Jos \\ 3.Department of Pharmacology, Faculty of Basic Clinical Sciences, College of Medical Sciences, Abubakar \\ Tafawa Balewa University (ATBU), Bauchi
}

\begin{abstract}
Diabetes mellitus is among the major global public health problems and its prevalence is currently increasing at an alarming rate. The research was carried out to evaluate the effect of aqueous fruit extract of Cucumis sativus on blood glucose, total protein, total bilirubin, cholesterol, triglycerides, low density lipoprotein (LDL), high density lipoprotein (HDL), urea, creatinine levels as well as aspartate aminotransferase (AST), alkaline Phosphatase (ALP) and electrolytes $\left(\mathrm{Na}^{+}, \mathrm{Cl}^{-}\right.$and $\left.\mathrm{HCO}_{3}^{-}\right)$levels on normal and streptozotocin induced-diabetic rat. The aqueous fruit extract was administered orally at a dose of $400 \mathrm{mg} / \mathrm{kg}$ body weight to both normal and streptozotocin induceddiabetic rat. Twenty adult male rats were divided into four groups of five rats each, two groups were made diabetic and the other two groups were non-diabetic. One of the diabetic groups were administered with the aqueous fruit extract and the second served as diabetic control. The streptozotocin was administered intraperitoneal at a dose of $55 \mathrm{mg} / \mathrm{kg}$ per body weight. The administration of the aqueous fruit extract lasted for 28 days. Effect of aqueous fruit extract on blood glucose, total protein, total bilirubin, cholesterol, triglycerides, LDL, HDL, urea, creatinine, and electrolytes $\left(\mathrm{Na}^{+}, \mathrm{Cl}^{-}\right.$and $\left.\mathrm{HCO}_{3}^{-}\right)$levels were analysed. The toxic effect of the aqueous fruit extract was determined using biochemical enzymes markers. The photochemical screening of the aqueous fruit extract showed the presences of Alkaloids, Balsam, Cyanogenic glycosides, Flavonoids, Saponins, Resins and Carbohydrate. Administration with the fruit extract showed significant $(\mathrm{P}<0.05)$ reduction on the serum blood glucose level and other biochemical parameters analyzed. The extract possesses no toxic effect as indicated by lowered AST and ALP levels and may be used for the management of diabetes mellitus.
\end{abstract}

Keywords: Cucumis sativus, Phytochemicals, Diabetic Mellitus, Liver enzymes, hypoglycemic activity.

DOI: $10.7176 /$ JNSR12-2-04

Publication date: January $31^{\text {st }} 2021$

\section{Introduction}

Diabetes mellitus is a non-communicable disease which have been shown to improve with medicinal plants. It is a metabolic disorder characterized by chronic hyperglycemia with disturbances of carbohydrate, fats and protein metabolism resulting from defects in insulin secretion, insulin action or both (WHO, 2006). Diabetes is also referred to as a syndrome of disorder in metabolism usually due to the combination of hereditary and environmental causes resulting in abnormally high blood sugar levels (hyperglycemia) (Mohammed et al., 2017). Blood glucose levels are controlled by a complex interaction of multiple chemical and hormones in the body including the hormones insulin made in beta cells of the pancreas. Diabetes mellitus develops due to diminished production of insulin (in type I) or resistances to its effects (in type II and gestational), both leads to hyperglycemia, which largely causes the acute signs of diabetes and changes in energy metabolism (Alhassan et al., 2017). As a result of the deficiency of insulin or inadequate insulin function there is an inadequate transfer of glucose into the cells; the utilization of glucose for energy and cellular products and its conversion to glycogen or fat and storage as such are depressed, thereby leading to accumulation of glucose in the blood, causing hyperglycemia (Muhammad et al., 2016). Fat may be mobilized from adipose tissue and broken down to provide a source of energy, which is eventually withdrawn from the body by the liver and broken down to glycerol and fatty acids leading to oxidation by the hepatic cells to ketone bodies and metabolizes by cells to produced energy, carbon dioxide and water (Rui, 2014). Only a limited amount of ketone acids can be utilized by cells as such if ketogenesis proceeds rapidly, exceeding the rate at which they can be metabolized, the ketone acids accumulate in the blood causing ketosis or ketone acidosis (Luka and Mohammed, 2012). Tissue protein may also be broken down to amino acids which are used in gluconeogenesis contributing to the hyperglycemia. Both the uptake of amino acids by the cells and body protein synthesis are decreased. Insulin-dependent diabetes mellitus (IDDM) usually has a sudden onset in a severe, acute form. In non-insulin-dependent diabetes mellitus (NIDDM) the onset is most often insidious going undetected and untreated for a considerable period of time (Rui, 2014).

Traditional medicine is the sum total of knowledge, skills and practices based on the theories, beliefs and experiences indigenous to different cultures that are used to maintain health, as well as to prevent, diagnosis, improve or treat physical and mental illness (Mahomoodally, 2013). Traditional medicines that have been adapted 
by other populations (outside its indigenous culture) are often termed alternative or complementary medicine. Herbal preparations and finished herbal products that contain parts of plants or other plants materials as active ingredients (Pan et al., 2014). Cucumis sativus is an annual climber growing up to $2 \mathrm{~m}$. The fruit is roughly cylindrical, elongated with tapered ends, and may be as large as $60 \mathrm{~cm}$ long and $10 \mathrm{~cm}$ in diameter (Uzodike and Onuoha, 2009). The cucumber is a common ingredient of salads, being valued mainly for its crisp texture and juiciness. However, it is very watery, with little flavor and is not very nutritious.

\section{Materials and Method}

\subsection{Sources of Plant Material and Preparation of Cucumber Juice}

The plant Cucumber (Cucumis sativus) fruits was obtained from Farin-gada area in Jos North Local Government, Plateau State. The plant was identified and authenticated at the Federal College of Forestry Jos North, Plateau State. The fresh Cucumber (Cucumis sativus) friuts were washed with clean water, sliced with knife and homogenized using an electric blender without addition of water. Grinder for 3 minutes and sieved to extract the filtrate.

\subsection{Source of Experimental Animals}

Twenty (20) adult male albino rats weighing approximately 80-150g were obtained from Animal House Unit Department of Pharmacology, University of Jos. The rats acclimatized to the laboratory condition for two weeks before any experimental work was undertaken, they were fed with standard feed.

\subsection{Preparation of Streptozotocin}

One gramme of Streptozotocin was dissolved in $10 \mathrm{mls}$ of distilled water for standardization and was used at once for inducing the experimental rats.

\subsection{Induction of Experimental Diabetes}

Diabetes was induced in groups A and B rats by intraperitoneal injection (IP) of streptozotocin at doses of $55 \mathrm{mg} / \mathrm{kg}$ body weight. Diabetes was confirmed in the animal after 48 hours by estimation of blood glucose level. Animals with blood glucose level above $200 \mathrm{mg} / \mathrm{dl}$ were selected.

\subsection{Administration of the Extract}

The Cucumis sativus fruit extract was administrated through the oral route at a dose of $400 \mathrm{mg} / \mathrm{kg}$ body weight daily for 28days.

\subsection{Experimental Design}

Twenty male rats were randomly divided into four groups of five rats each and fed with standard feed as follows: Group A - Diabetic control rats with no administration of extract (negative control).

Group B - Diabetic rats given extract $(400 \mathrm{mg} / \mathrm{kg}$ ) body weight daily for 28 days.

Group C - Normal rats with no administration of extract (positive control).

Group D - Normal rats given extract $(400 \mathrm{mg} / \mathrm{kg})$ body weight daily for 28 days.

\subsection{Sample Collection and Preparation}

At the end of 28 days of extract administration, blood from the animals (both treated and control groups) were collected from the jugular vein into plan bottles. The blood in the plain bottle were allowed to clot at room temperature. The clotted blood sample were ringed and centrifuged for 10 minutes at 5,000 r.p.m. Pasteur pipette were used to separate the serum (supernatant) into clean bottles. The serum were used for the biochemical assay.

\subsection{Statistical Analysis}

Results were expressed as mean \pm standard deviation and analyzed using ANOVA, with $p$ value $<0.05$ considered significant followed by Tukey's post hoc test. A component of Graph Pad Instat3 Software 2000 version 3.05 by Graph Pad Inc was used to analyze the data.

\subsection{Results}

Table 1 shows the results obtained when aqueous extracts was screened for phytochemicals such as Alkaloids, balsam, cardiac glycosides, flavonoids, saponins, terpenes and steroids, phenols, resins, carbohydrates and tannins. All were detected except for terpenes and steroids, phenols and Tannins. 
Table 1: Result of phytochemical screening of freshly prepared Cucumis sativus extract.

\begin{tabular}{|l|l|c|}
\hline Bioactive constituents & Chemical test & Aqueous extract \\
\hline Alkaloids & Dragendrorff & + \\
Balsam & Alcoholic FeCl3 & + \\
Cyanogenic glycosides & Salkowski & + \\
Flavonoids & Lead acetate & + \\
Saponins & General test & - \\
Terpenes and steroids & General test & + \\
Phenols & General test & + \\
Resins & General test & - \\
Carbohydrate & General test & Ferric chloride \\
\hline
\end{tabular}

$+=$ present, $-=$ absent.

Table 2 shows serum glucose, total protein levels in the diabetic and normal groups of rats. The diabetic rats showed a significant $(\mathrm{P}<0.05)$ increase in serum glucose when compared with normal control rats while significant $(\mathrm{P}<0.05)$ decrease in total protein was observed when compared to normal control rats. On administration of Cucumis sativus aqueous extract there was a significant decrease $(\mathrm{P}<0.05)$ in serum glucose when compared with the diabetic control rats. However, there was significant $(\mathrm{P}<0.05)$ increase in total protein level when compared with diabetic control rats.

Table 2: Effect of Cucumis sativus aqueous extract on serum glucose and total protein levels in streptozotocin induced diabetic rats.

\begin{tabular}{|l|l|l|}
\hline Groups & Glucose $(\mathbf{m m o l} / \mathbf{L})$ & Total Protein $(\mathbf{g} / \mathbf{L})$ \\
\hline Diabetic Control & $17.83 \pm 0.175$ & $65.55 \pm 0.286$ \\
\hline Diabetic + Extract & $6.85 \pm 0.198^{\mathrm{a}}$ & $76.88 \pm 0.029^{\mathrm{a}}$ \\
\hline Normal Control & $3.39 \pm 0.223^{\mathrm{a}}$ & $78.86 \pm 0.085^{\mathrm{a}}$ \\
\hline Normal + Extract & $4.70 \pm 0.151^{\mathrm{a}}$ & $75.38 \pm 0.089^{\mathrm{a}}$ \\
\hline
\end{tabular}

Values are presented as mean $\pm \mathrm{SD}, \mathrm{n}=6$

$\mathrm{a}=$ statistically significant when compared with diabetic control $(\mathrm{P}<0.05)$

Table 3 shows total cholesterol, triglyceride, low density lipoprotein (LDL) and high density lipoprotein (HDL) levels in the diabetic and normal groups of rats. The diabetic rats showed a significant $(\mathrm{P}<0.05)$ increase in all the parameters when compared with normal control rats except for high density lipoprotein level which showed a significant $(\mathrm{P}<0.05)$ decrease when compared with normal control rats. On administration of Cucumis sativus aqueous extract there was a significant $(\mathrm{P}<0.05)$ decrease when compared with the diabetic control rats except for high density lipoprotein which showed significant $(\mathrm{P}<0.05)$ increase.

Table 3: Effect of Cucumis sativus aqueous extract on serum lipid profile levels in streptozotocin induced diabetic rats.

\begin{tabular}{|l|l|l|l|l|}
\hline Groups & $\begin{array}{l}\text { Total Cholesterol } \\
(\mathbf{m m o l} / \mathbf{L})\end{array}$ & $\begin{array}{l}\text { Triglyceride } \\
(\mathbf{m m o l} / \mathbf{L})\end{array}$ & LDL (mmol/L) & HDL (mmol/L) \\
\hline Diabetic Control & $5.44 \pm 0.263$ & $2.20 \pm 0.062$ & $2.70 \pm 0.200$ & $0.38 \pm 0.017$ \\
\hline Diabetic + Extract & $3.97 \pm 0.188^{\mathrm{a}}$ & $1.22 \pm 0.035^{\mathrm{a}}$ & $1.59 \pm 0.014^{\mathrm{a}}$ & $1.27 \pm 0.053^{\mathrm{a}}$ \\
\hline Normal Control & $3.20 \pm 0.072^{\mathrm{a}}$ & $0.99 \pm 0.005^{\mathrm{a}}$ & $1.00 \pm 0.037^{\mathrm{a}}$ & $1.75 \pm 0.073^{\mathrm{a}}$ \\
\hline Normal + Extract & $3.52 \pm 0.098^{\mathrm{a}}$ & $1.20 \pm 0.053^{\mathrm{a}}$ & $1.11 \pm 0.054^{\mathrm{a}}$ & $1.55 \pm 0.042^{\mathrm{a}}$ \\
\hline
\end{tabular}

Values are presented as mean $\pm \mathrm{SD}, \mathrm{n}=6$

$\mathrm{a}=$ statistically significant when compared with diabetic control $(\mathrm{P}<0.05)$

Table 4 shows result of ALT, AST, ALP, Albumin, Total Bilirubin and Direct bilirubin levels in diabetic and normal groups of rats. The diabetic rats administered with the aqueous extract showed significant $(\mathrm{P}<0.05)$ decrease in all the parameters analyzed except for albumin which showed significant $(\mathrm{P}<0.05)$ increase when 
compared with diabetic control rats.

Table 4: Effect of Cucumis sativus extract on liver marker enzymes on streptozotocin induced diabetic rats.

\begin{tabular}{|l|l|l|l|l|l|l|}
\hline Groups & ALT(U/L) & AST (U/L) & ALP(U/L) & $\begin{array}{l}\text { Albumin } \\
(\mathbf{g} / \mathbf{L})\end{array}$ & $\begin{array}{l}\text { T. } \\
\text { Bilurubin } \\
(\boldsymbol{\mu m o l} / \mathbf{L})\end{array}$ & $\begin{array}{l}\text { D. } \\
\text { Bilurubin } \\
(\boldsymbol{\mu m o l} / \mathbf{L})\end{array}$ \\
\hline $\begin{array}{l}\text { Diabetic } \\
\text { Control }\end{array}$ & $44.37 \pm 0.221^{\mathrm{b}}$ & $46.30 \pm 15.227^{\mathrm{b}}$ & $389.99 \pm 0.066^{\mathrm{b}}$ & $30.64 \pm 0.069^{\mathrm{a}}$ & $34.25 \pm 0.189^{\mathrm{b}}$ & $21.95 \pm 0.077^{\mathrm{b}}$ \\
\hline $\begin{array}{l}\text { Diabetic } \\
\text { Extract }\end{array}$ & $15.83 \pm 0.164^{\mathrm{bc}}$ & $17.48 \pm 0.198^{\mathrm{bc}}$ & $160.99 \pm 0.559^{\mathrm{bc}}$ & $36.71 \pm 0.179^{\mathrm{ad}}$ & $14.90 \pm 0.095^{\mathrm{bc}}$ & $4.51 \pm 0.269^{\mathrm{bc}}$ \\
\hline $\begin{array}{l}\text { Normal } \\
\text { Control }\end{array}$ & $11.22 \pm 0.098$ & $15.41 \pm 0.188$ & $134.43 \pm 0.322$ & $38.77 \pm 0.112$ & $9.55 \pm 0.152$ & $3.82 \pm 0.103$ \\
\hline $\begin{array}{l}\text { Normal } \\
\text { Extract }\end{array}$ & $16.09 \pm 0.066^{\mathrm{bc}}$ & $18.24 \pm 0.148^{\mathrm{bc}}$ & $246.64 \pm 0.234^{\mathrm{bc}}$ & $37.74 \pm 0.179^{\mathrm{ad}}$ & $10.27 \pm 0.173^{\mathrm{bc}}$ & $4.16 \pm 0.127^{\mathrm{bc}}$ \\
\hline
\end{tabular}

Values are presented as mean $\pm \mathrm{SD}, \mathrm{n}=6$

$\mathrm{a}=$ statistically significant when compared with diabetic control $(\mathrm{P}<0.05)$

Table 5 shows the result of Urea, creatinine, $\mathrm{Na}^{+}, \mathrm{K}^{+}, \mathrm{Cl}^{-}$and $\mathrm{HCO}_{3}{ }^{-}$levels in diabetic and normal groups of rats. The diabetic rats administered with the extract showed significant $(\mathrm{P}<0.05)$ decrease in Urea, creatinine and $\mathrm{K}^{+}$levels when compared to diabetic control rats while $\mathrm{Na}^{+}, \mathrm{Cl}^{-}$and $\mathrm{HCO}_{3}{ }^{-}$levels where significant $(\mathrm{P}<0.05)$ increase when compared with diabetic control rats.

Table 5: Effect of Cucumis sativus on kidney parameters in streptozotocin induced diabetic rats.

\begin{tabular}{|l|l|l|l|l|l|l|}
\hline Groups & $\begin{array}{l}\text { Urea } \\
(\mathbf{m m o l} / \mathbf{L})\end{array}$ & $\begin{array}{l}\text { Creatinine } \\
(\boldsymbol{\mu m o l} / \mathbf{L})\end{array}$ & $\mathbf{N a}^{+}(\mathbf{m m o l} / \mathbf{L})$ & $\mathbf{K}^{+}(\mathbf{m m o l} / \mathbf{L})$ & $\mathbf{C l}^{-}(\mathbf{m m o l} / \mathbf{L})$ & $\begin{array}{l}\mathbf{H C O}^{-} \\
(\mathbf{m m o l} / \mathbf{L})\end{array}$ \\
\hline $\begin{array}{l}\text { Diabetic } \\
\text { Control }\end{array}$ & $19.94 \pm 0.059$ & $378.44 \pm 0.303$ & $135.56 \pm 0.550$ & $6.38 \pm 0.181$ & $98.52 \pm 0.321$ & $15.44 \pm 0.294$ \\
\hline $\begin{array}{l}\text { Diabetic }+ \\
\text { Extract }\end{array}$ & $5.60 \pm 0.066^{\mathrm{a}}$ & $104.73 \pm 0.204^{\mathrm{a}}$ & $138.58 \pm 0.385^{\mathrm{a}}$ & $4.24 \pm 0.085^{\mathrm{a}}$ & $109.12 \pm 0.072^{\mathrm{a}}$ & $25.25 \pm 0.163^{\mathrm{a}}$ \\
\hline $\begin{array}{l}\text { Normal } \\
\text { Control }\end{array}$ & $3.98 \pm 0.020^{\mathrm{a}}$ & $69.93 \pm 0.110^{\mathrm{a}}$ & $144.59 \pm 0.305^{\mathrm{a}}$ & $3.93 \pm 0.208^{\mathrm{a}}$ & $115.61 \pm 0.314^{\mathrm{a}}$ & $27.33 \pm 0.229^{\mathrm{a}}$ \\
\hline $\begin{array}{l}\text { Normal }+ \\
\text { Extract }\end{array}$ & $5.95 \pm 0.081^{\mathrm{a}}$ & $82.86 \pm 0.142^{\mathrm{a}}$ & $140.57 \pm 0.396^{\mathrm{a}}$ & $4.63 \pm 0.316^{\mathrm{a}}$ & $110.58 \pm 0.301^{\mathrm{a}}$ & $23.91 \pm 0.420^{\mathrm{a}}$ \\
\hline
\end{tabular}

Values are presented as mean $\pm \mathrm{SD}, \mathrm{n}=6$

$\mathrm{a}=$ statistically significant when compared with diabetic control $(\mathrm{P}<0.05)$

\subsection{Discussion}

Diabetes is induced by streptozotocin a glucosamine-nitrosurea compound derived from stretomycesachromo genes that is used clinically as a chemotherapeutic agent in the treatment of pancreatic and cell carcinoma. Streptozotocin damages pancreatic beta-cell, resulting in hypoinsulinemia and hyperglycemia (Graham et al., 2011). The result of the present study confirms that the administration of Cucumis sativus juice possesses anti diabetic activity against streptozotocin induced diabetic rats. The finding is in accordance to research of Luka and Mohammed, (2012) which showed mark decrease in blood glucose level of rats induced with alloxan when administered with extract of Mangifera indica leaf. The anti-diabetic effect may be due to increased release of insulin from the existing beta-cells of pancreas.

Diabetes mellitus is also associated with hyperlipidaemia with profound alteration in the concentration and composition of lipid (Odetola et al., 2006). Changes in the concentration of the lipid with diabetes mellitus contribute to the development of vascular disease (Pari et al., 2007, Schofield et al., 2016). Fatty acid, an important component of cell membranes are eicosanoid precursors and are therefore required for both the structure and function of every cell in the body (Rajasekaran et al., 2006). Lipid profiles have been shown to be the important predictors for the metabolic disturbances including dyslipidemia, hypertension, diabetes, cardiovascular disease, hyperinsulinemia etc. (Kaur, 2014). Administration of aqueous extract of Cucumis sativus fruit caused antihyperlipidaemia which have been reported in similar findings of Mohammed et al., (2017) which showed significant $(\mathrm{p}<0.05)$ decrease in serum cholesterol, triglycendes and LDL levels with corresponding increase in HDL level when rats induced with alloxan and were administered with Cocos nucifera oil, and Luka et al., (2013) also showed significant $(\mathrm{p}<0.05)$ decrease in serum cholesterol and triglycendes levels with corresponding increase in HDL level when rats induced with alloxan were administered with aqueous extract of Mangifera indica leaf.

Damage to the liver is a serious disease characterized by disturbances in normal functions of the liver. It is clinically diagnosed by determining the serum concentration of liver enzymes (ALT, AST and ALP). These 
enzymes are non-plasma specific enzymes and were reported to reach higher than normal levels in the blood when there is necrosis of the parenchymal cells of the liver as in viral or toxic hepatitis, with ALT being the most specific liver injury marker and a more selective liver parenchymal enzyme (Alhassan et al., 2017). Alkaline phosphatase (ALP) test is also used to detect bone disorders. In conditions affecting the liver, damaged liver cells release increased amounts of ALP into the blood. This test is often used to detect blocked bile ducts because ALP is especially high in the edges of cells that join to form bile ducts. If one or more of them are obstructed, then blood levels of ALP will often be high (Sherlock and Dooley, 2002). However, the difference observed in the activities of these enzymes at the dose employed $(400 \mathrm{mg} / \mathrm{kg}$ body weight) showed that Cucumis sativus fruit extract has no toxic effect on the liver of the rats. This is similar to finding of Luka et al., (2013) which showed statistically significant $(\mathrm{P}<0.05)$ decrease in ALT, AST, ALP, total bilirubin and direct bilirubin levels when rats were administered with Thymus Vulgaris and Xylopia Aethiopica extract with significant $(\mathrm{P}<0.05)$ increase in Albumin level when compared with diabetic control group.

Kidneys are the major organs in metabolizing toxic compound besides liver. It receives about $1200 \mathrm{ml}$ of blood per minute containing a lot of chemical compounds (Dollah et al., 2013). Therefore, damage to the kidneys can be determined by measuring the level of urea, electrolyte and creatinine in blood as an indicator of kidney damage. Administration of $400 \mathrm{mg} / \mathrm{kg}$ body weight of Cucumis sativus fruit extract showed electrolytes balanced, this findings support the report of Ngwen et al., (2018) which showed significant $(\mathrm{p}<0.05)$ increase in $\mathrm{Na}^{+}, \mathrm{Cl}^{-}$and $\mathrm{HCO}_{3}{ }^{-}$with concomitant reduction in $\mathrm{K}^{+}$in diabetic administered with Buchholzia coriacae extract. Also, diabetic administered with $400 \mathrm{mg} / \mathrm{kg}$ body weight of Buchholzia coriacae extract showed significant $(\mathrm{P}<0.05)$ decrease in urea, and creatinine levels when compared with diabetic control group. Also similar findings in the case of ${ }^{[18]}$ showed significant $(\mathrm{p}<0.05)$ increase in $\mathrm{Na}^{+}, \mathrm{Cl}^{-}$and $\mathrm{HCO}_{3}{ }^{-}$with reduction in $\mathrm{K}^{+}$in diabetic administered with Curcuma longa Linn root extracts. Also, diabetic administered with Curcuma longa Linn root extracts showed significant $(\mathrm{P}<0.05)$ decrease in urea, and creatinine levels when compared with diabetic control group.

\subsection{Conclusion}

Administration of Cucumis sativus fruit extract decreased the concentration of blood glucose as well as protein in streptozotocin induced diabetic rats. Therefore, the friut have hypoglycaemic effects. The study also showed that Cucumis sativus fruit may not have toxic effect on the liver at the employed dosage since it produced no significant effects on the enzymes activities as biochemical enzymes makers of liver damage.

\subsection{Ethical approval}

All authors hereby declare that Principle of laboratory animal care and ethical guidelines for investigation of experimental pain in conscious animals were observed during experimentation (Zimmermann, 1983; NIH, 1996).

\subsection{Competing interests}

Authors have declared that no competing interests exist.

\subsection{Consent}

It is not applicable.

\section{References}

1. WHO. (2006). "Definition and diagnosis of diabetes mellitus and intermediate hyperglycaemia." Geneva, Switzerland. Pp. $5-7$

2. Mohammed. A, Wudil. A.M, Alhassan. A.J, Imam. A.A, Muhammad. I.U, \& Idi. A. (2017). Hypoglycemic Activity of Curcuma longa Linn Root Extracts on Alloxan Induced Diabetic Rats. Saudi Journal of Life Science, 2(2): 43-49.

3. Alhassan. A.J, Muhammad. I.U, Sule. M.S, Wudil. A.M, Imam. A.A, Idi. A, Muhammad. A, Mohammed. A, Alexander, I. \& Nasir, A. (2017). Characterization and Anti-Diabetic Activity of Dihydrophenantherene Isolated from Khaya senegalensis Stem Bark. Annual Research \& Review in Biology. 17(2): 1-17, 2017.

4. Muhammad, I.U., Alhassan, A.J., Sule, M.S., Idi, A., Mohammed, A., El- ta'alu, A.B., Dangambo, M.A., \& Abdulmumin, Y. (2016). Anti-Hyperglycemic Activity of Solvents Extract of Khaya senegalensis Stem Bark in Alloxan Induced Diabetic Rats. Journal of Advances in Biology \& Biotechnology, 6(2): 1-8.

5. Rui L. (2014). Energy metabolism in the liver. Comprehensive Physiology, 4(1), 177-197.

6. Luka C.D \& Mohammed, A. (2012) Effect of Aqueous Extract of Dioscorea Bulbifera on Some Biochemical Parameters in Alloxan- Induced Diabetic Rats. Journal of Medical and Applied Biosciences.4:53-60.

7. Mahomoodally M. (2013). "Traditional Medicines in Africa: An Appraisal of Ten Potent African Medicinal Plants", Evidence-Based Complementary and Alternative Medicine, vol. 2013, Article ID 617459, 14 pages.

8. Pan, S. Y., Litscher, G., Gao, S. H., Zhou, S. F., Yu, Z. L., Chen, H. Q., Zhang, S. F., Tang, M. K., Sun, J. N. \& Ko, K. M. (2014). Historical perspective of traditional indigenous medical practices: the current 
renaissance and conservation of herbal resources. Evidence-based complementary and alternative medicine: eCAM, 2014, 525340.

9. Uzodike, E. B. \& Onuoha, I. N. (2009). The effect of Cucumber (Cucumbis savitus) extract on acid induced corneal burn in guinea pigs. Journal of the nigerian optimetric association. 15: 3-7.

10. Graph Pad Instat 3 Software. (2000). Available: www.graphpad.com. Retrieve on 14rd October, 2020.

11. Graham, M. L., Janecek, J. L., Kittredge, J. A., Hering, B. J. \& Schuurman, H. J. (2011). The streptozotocininduced diabetic nude mouse model: differences between animals from different sources. Comparative medicine, 61(4), 356-360.

12. Luka C.D \& Mohammed, A. (2012). Effect of Aqueous Extract of Dioscorea Bulbifera on Some Biochemical Parameters in Alloxan- Induced Diabetic Rats. Journal of Medical and Applied Biosciences.4:53-60.

13. Odetola, A. A., Akinloye, O., Egunjobi, C., Adekunle, W. A. \& Ayoola,A O. (2006). Possible antidiabetic and antihyperlipidaemic effect of fermented Parkia biglobosa (JACQ) extract in alloxan-induced diabetic rats. Clin. Exp. Pharmacol. Physiol., 33: 808-812.

14. Pari, L. \& Murugan, P. (2007). Antihyperlipidemic Effect of Curcumin and Tetrahydrocurcumin in Experimental Type 2 Diabetic Rats, Renal Failure, 29(7): 881-889.

15. Schofield, J. D., Liu, Y., Rao-Balakrishna, P., Malik, R. A. \& Soran, H. (2016). Diabetes Dyslipidemia. Diabetes therapy: research, treatment and education of diabetes and related disorders, 7(2): 203-219.

16. Rajasekaran, S., Ravi, K., Sivagnanam, K. \& Subramanian, S. (2006). Beneficial effects of Aloe vera leaf gel extract on lipid profile status in rats with streptozotocin diabetes. Clin. Exp. Pharmacol. Physiol., 33: 232237.

17. Kaur, J. (2014). A comprehensive review on metabolic syndrome. Cardiology research and practice, 943162.

18. Mohammed, A., Luka, C. D., Gyang, S. D., \& Ngwen, A.L. (2017). Evaluation of the effect of coconut oil (Cocos nucifera) on some biochemical parameters in alloxan-induced diabetic rats. Saudi Journal of Medical Pharmaceutical Sciences 3(4): 318-322.

19. Luka, C. D., Mohammed, A. \& Ngwen A. L. (2013). Phytochemical Screening of Thyme (Thymus Vulgaris) and Negro Pepper (Xylopia Aethiopica) and the Effects of their extracts on Some Biochemical Parameters in albino rats. Biological and Environmental Sciences Journal for the tropics. 10(4): 137-141.

20. Alhassan. A. J., Kiru. A. I., Dangambo. M. A., Gadanya. A. M., Imam. A. A., Muhammad. I. U., El- ta'alu. A. B. \& Mohammed. A. (2017). Effects of Aqueous and Chloroform Stem Bark Extracts of Alstonia boonei on Liver Function Indices of Plasmodium Berghei Induced Albino Mice. Journal of Natural Sciences Research, 7(22): 16-21.

21. Sherlock, S. \& Dooley, J. (2002). Drugs and liver. In: Disease of liver Biliary System. 11th edition. Oxford: Blackwell Science Publishers. 322 - 356.

22. Dollah, M. A., Parhizkar, S., \& Izwan, M. (2013). Effect of Nigella sativa on the kidney function in rats. Avicenna J Phytomed Spring, 3(2): 152-158.

23. Ngwen, A.L., Mohammed, A., Japheth, C., Mhya, H.D., \& Omale, O.F.R. (2018). Evaluation of The Effects of Methanol Extracts of Leaf and Stem Bark of Buchholzia coriacae (Wonderful Kola) on Some Biochemical Parameters of Streptozotocin-Induced Diabetic Rats. Journal of Biotechnology and Biochemistry 4(2); 01-08.

24. Zimmermann, M. (1983). Ethical guidelines for investigations of experimental pain in conscious animals. Pain, 16(2): 109-110. 